\title{
Untreated obstructive sleep apnoea as a therapeutic target in acute aortic dissection
}

\author{
Toru Inami, ${ }^{1}$ Yoshihiko Seino, ${ }^{1}$ Ryuzo Bessho, ${ }^{2}$ Kyoichi Mizuno ${ }^{3}$ \\ ${ }^{1}$ Department of Cardiology, Nippon Medical School Chiba Hokusoh Hospital, Chiba, Japan \\ ${ }^{2}$ Department of Thoracic and Cardiovascular Surgery, Nippon Medical School Chiba Hokusoh Hospital, Chiba, Japan \\ ${ }^{3}$ Department of Cardiovascular Medicine, Nippon Medical School, Tokyo, Japan
}

Correspondence to Dr Toru Inami, t-inami@nms.ac.jp

\section{DESCRIPTION}

A 59-year-old man developed sudden onset of chest pain and was admitted to our hospital. Emergent contrastenhanced CT showed the development of retrograde-type A aortic dissection (AD) with patent false lumen in the descending aorta and thrombosed false lumen in the ascending aorta (figure 1). The patient was treated with intensive drug therapy. We evaluated blood pressure (BP) variability by ambulatory BP monitoring (ABPM), which revealed that the mean $\mathrm{BP}$ over $24 \mathrm{~h}$ was $150 / 75 \mathrm{~mm} \mathrm{Hg}$ with a typical morning surge (figure 2B) despite a combination of several antihypertensive medications for previous 1 month such as amlodipine besilate $10 \mathrm{mg}$, telmisartan $80 \mathrm{mg}$, bisoprolol fumarate $5 \mathrm{mg}$, doxazosin mesilate $8 \mathrm{mg}$, eplerenone $50 \mathrm{mg}$, trichlormethiazide $2 \mathrm{mg}$ and methyldopa $50 \mathrm{mg} /$ day. Obstructive sleep apnoea (OSA) has been reported as a cause of drug-resistant hypertension, ${ }^{1}$ so we performed sleep polygraphic study. This revealed severe OSA with an apnoea-hypopnea index of $56.7 / \mathrm{h}$ and lowest percutaneous oxygen saturation of $84 \%$ (figure 2A).We started continuous positive airway pressure (CPAP) for the treatment of OSA. Two weeks after the introduction of CPAP, follow-up ABPM revealed a marked decrease in mean systolic and diastolic BP to $126 / 66 \mathrm{~mm} \mathrm{Hg}$ (figure 2C). History of hypertension is the most common predisposing factor for $\mathrm{AD} .^{2}$ The presence of OSA is associated with increased risk of incident hypertension, and treatment with CPAP therapy reduces this

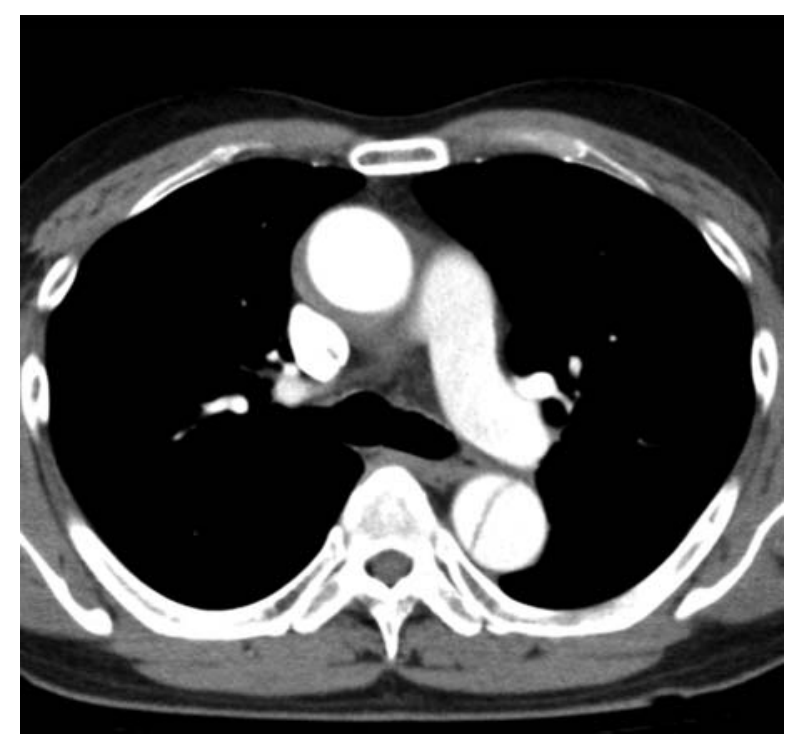

Figure 1 Contrast-enhanced CT illustrates the development of retrograde type $A$ aortic dissection with patent false lumen in descending aorta.

risk. ${ }^{3}$ The present case suggested that OSA should be considered in the differential diagnosis of resistant hypertension in the recovery period following dissection. As a specific treatment for OSA, CPAP would assist the

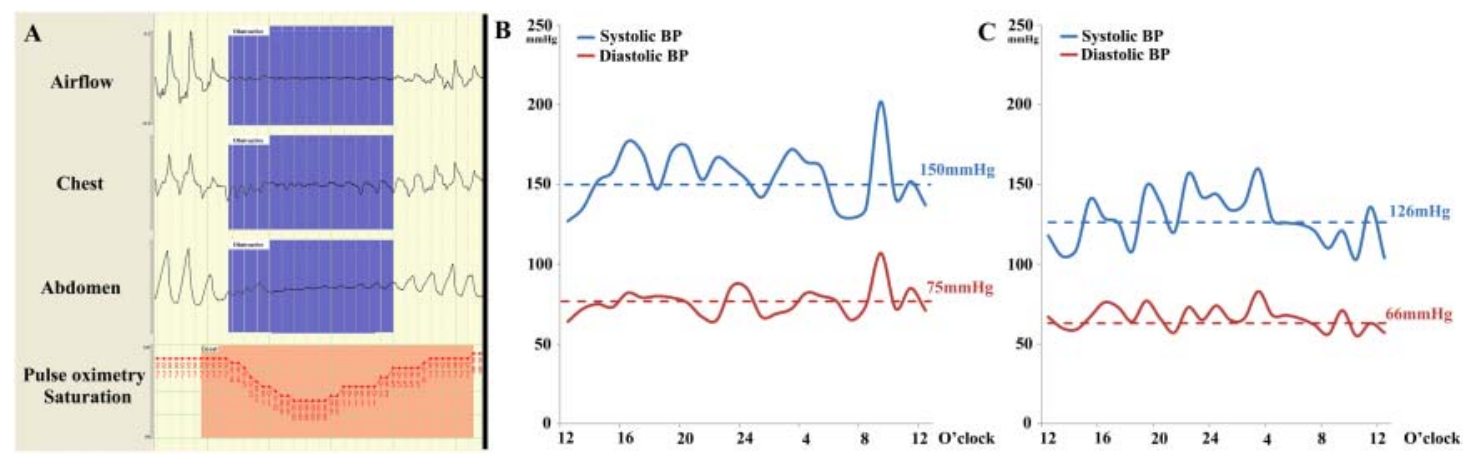

Figure 2 (A) The sleep polygraphic study illustrated the severe desaturation accompanied with obstructive apnoea. (B) The ABPM before CPAP treatment showed uncontrolled high BP. Blue and red dotted lines presented mean systolic and diastolic BP during whole day. (C) The variability of BP after introduction of CPAP treatment illustrated decreased systolic and diastolic BP compared to those before CPAP treatment. ABPM, ambulatory blood pressure monitoring; CPAP, continuous positive airway pressure; BP, blood pressure. 


\section{BMJ Case Reports}

management of drug-resistant hypertension, however $\mathrm{CPAP}$ has not yet been proven to reduce the risk of $\mathrm{AD}$. Among patients with $\mathrm{AD}$, OSA should be considered in the differential diagnosis of drug-resistant hypertension, which is a major risk factor for $\mathrm{AD}$.

\section{LEARNING POINTS}

- Obstructive sleep apnoea (OSA) is an important cause of drug-resistant hypertension.

- continuous positive airway pressure well reduced BP through whole day and achieved well-controlled variability of BP.

- The presence of OSA should be evaluated in the therapeutic strategies of aortic dissection.

- This case describes a link between aortic dissection and OSA.
Competing interests None.

Patient consent Obtained.

\section{REFERENCES}

1. Logan AG, Perlikowski SM, Mente A, et al. High prevalence of unrecognized sleep apnoea in drug-resistant hypertension. $J$ Hypertens 2001:19:2271-7.

2. Hagan PG, Nienaber CA, Isselbacher EM, et al. The International Registry of Acute Aortic Dissection (IRAD): new insights into an old disease. JAMA 2000;283:897-903.

3. Pedrosa RP, Drager LF, Gonzaga CC, et al. Obstructive sleep apnea: the most common secondary cause of hypertension associated with resistant hypertension. Hypertension 2011;58:811-17.

Copyright 2012 BMJ Publishing Group. All rights reserved. For permission to reuse any of this content visit http://group.bmj.com/group/rights-licensing/permissions.

BMJ Case Report Fellows may re-use this article for personal use and teaching without any further permission.

Please cite this article as follows (you will need to access the article online to obtain the date of publication).

Inami T, Seino Y, Bessho R, Mizuno K. Untreated obstructive sleep apnoea as a therapeutic target in acute aortic dissection. BMJ Case Reports 2012;10.1136/bcr-2012-006843, Published XXX

Become a Fellow of BMJ Case Reports today and you can:

- Submit as many cases as you like

- Enjoy fast sympathetic peer review and rapid publication of accepted articles

- Access all the published articles

- Re-use any of the published material for personal use and teaching without further permission

For information on Institutional Fellowships contact consortiasales@bmjgroup.com

Visit casereports.bmj.com for more articles like this and to become a Fellow 